\title{
THE VALUATION OF CLOSE HELD STOCKS : A LOTTERY IN FEDERAL TAXATION
}

\author{
By Ralph S. Rice $\dagger$
}

The importance of the problem of valuation in federal taxation has been exceeded only by its neglect. In the estate tax field, particularly, volumes have been written about the items which are included in the net estate, but relatively little attention has been paid to the problem of translating those items into dollar figures for the purpose of computing the tax. Consideration of the subject has heretofore been limited to general conclusions that valuation is such a subjective process that firm and fixed formulae cannot be invoked to reach a computation of the dollar value of property for purposes of taxation, ${ }^{1}$ and a listing of the multiple "factors" which the Commissioner and the courts have considered in making such a computation. ${ }^{2}$ We have, in fact, been so busy classifying the "factors" bearing on value that we have rarely stopped to consider whether Congress (and the Commissioner in the exercise of his rule making power) should substitute firm legislative standards of value for subjective judgments respecting value made on an $a d$ hoc basis by the Commissioner and the courts.

It is the purpose of this article to examine the theory under which determinations of "value" have been left to the largely unicontrolled discretion of the Commissioner and the courts which directly review his determination; to review the actual operation of the theory; and to suggest a practical method of improving the present system of valuations for Federal tax purposes, particularly with respect to stocks as to which no market data is available.

A consideration of the problem may properly be initiated by reference to first principles. It is clear that the amount of Federal estate

† Professor of Law, University of Cincinnati.

1. Meadow Land and Improvement Co. v. Commissioner, 124 F.2d 297 (3d Cir. 1941); Emerald Oil Co. v. Commissioner, 72 F.2d 681 (10th Cir. 1934); James P. Hooper, 41 B.T.A. 114 (1940); Daniel Guggenheim, 39 B.T.A. 251 (1939) ; William Winder Laird, 38 B.T.A. 926 (1938) ; James Couzens, 11 B.T.A. 1040, (1928). This approach pervades many decisions. See Judge Frank's comment in Commissioner v. Marshall, 125 F.2d 943 (2d Cir. 1942) ; Texas-Empire Pipe Line Co. v. Commissioner, 127 F.2d 220 (10th Cir. 1942); Andrews v. Commissioner, 135 F.2d 314 (2d Cir. 1943). See also U.S. Treas. Regs. 29.111-1 (1941).

2. See 10A Mertens, The Law of Federal Income Taxation 4-150 (1948); 2 PaUl, Estate aNd Gift Taxation 1212-1345 (1942). There is an excellent compilation of earlier cases respecting "factors" to be considered in valuing stock having no market price in 103 A.L.R. 955-977 (1936). An illustration of the use of various factors is found infra, notes 26 to 32 , and text. 
and gift taxes should be fixed by what is transferred, the amount of the tax increasing with the dollar equivalent of the property. Accordingly, if a decedent leaves cash, a partnership interest, stocks and real estate, it is necessary to establish a dollar figure for the partnership interest, stocks and real estate. The same problem arises where a gift of property is involved. Similarly, where a taxpayer exchanges property for other property, it may be necessary to establish a dollar equivalent for the property received to ascertain whether he realized a gain on the transaction for Federal income tax purposes. $^{3}$

In any case the interpretation of the property in terms of dollar equivalents is imperative. The bases for such an interpretation necessarily must be artificial in the absence of sale of all items of the property on the open market at the critical date. In such a case, it is the duty of Congress and the Commissioner to set out, with such clarity as circumstances permit, the standards by which this artificial figure of dollar equivalents shall be established. It is not necessarily a problem related to "what is value"-a problem which has received not infrequent philosophical attention with roughly the same results that accompanied Pilate's inquiry of "what is truth." It is a practical problem of what standard will relieve the complexities of tax administration (which burden not only the Commissioner but the taxpayer and his lawyer as well), to the maximum extent compatible with fair treatment for the taxpayer.

The Federal income, gift and estate tax statutes currently reflect only a disposition to ignore the problem. Instead of meeting the problem squarely with a considered attempt at solution, Congress has evaded it by references to "value," one of the most slippery of words." The estate tax statutes provide that the tax shall be measured by

3. Valuation for income tax purposes may be important in various circumstances. See statutory references listed infra, note 7 , respecting determination of amounts received on sale of property; establishment of a "value" for property as of March 1, 1913; valuation of property received or delivered in an exchange; and establishment of a basis for property received by gift or bequest.

4. The various uses of the word were discussed in a relatively early study by Bonbright, The Problems of Judicial Valuation, 27 CoL. L. REv. 493 (1927). Illustrations of the elusive nature of the word are manifold. An eloquent and much quoted analysis of the meaning of the word was made by Judge Frank in rejecting a claim that a formula for determining "value" based on mortality tables did not result in the fair value of the property to the taxpayer. He suggested that it would be improper to adopt an approach which "would preclude a tax on any 'value' which is not almost certain to correspond with actual enjoyment. 'Value' seldom does so correspond. The fallacy in that argument stems largely from lack of recognition of the eely character of the word 'value.' It is a bewitching word which, for years, has disturbed mental peace and caused numerous useless debates. Perhaps it would be better for the peace of men's minds if the word were abolished. Reams of good paper and gallons of good ink have been wasted by those who have tried to give it a constant and precise meaning." Commissioner v. Marshall, 125 F.2d 943, 946 (2d Cir. 1942). See also notes $36,37,55$, and 56 , infra. 
the "value" of the net estate." A similar provision is made in the gift tax statute. ${ }^{8}$ Under the income tax provisions measurement of taxable gains is made on the basis of the "fair market value" of the property sold or received. ${ }^{7}$

The terms have been interpreted in the regulations of the Commissioner. With respect to the estate tax, the regulations provide that "value" means "fair market value"; ${ }^{8}$ that stock which is listed or otherwise has a market shall be valued at the mean average of the sale prices on the critical date, and if there were no sales then on the mean average between the sales prices on the nearest date before and after the valuation date; that if no sales have been made, the mean between the bid and asked prices may be used; and that where actual sales or bona fide bid and asked prices are not available, the value of stocks and bonds is to be determined through reference to certain specific and "all other relevant" factors. ${ }^{9}$ The formula substantially reduces speculation respecting stock having a market price, notwithstanding that an escape clause permits variation in cases where use of the formula would not result in "fair market value." 10 The regulations make specific reference to business interests, notes, cash, household goods and personal effects. Such references reiterate reliance on the general concept of "fair market value" and the price which "a will-

5. INT. REV. CODE $\$ 810,811(\mathrm{a}) . \$ 811(\mathrm{k})$ provides in substance that where no market price is available for stock. . "the value thereof shall be determined taking into consideration, in addition to all other factors, the value of stock or securities of corporations engaged in the same or a similar line of business which are listed on an exchange."

6. Id. $\$ 1005$ : "If the gift is made in property, the value thereof at the date of the gift shall be considered the amount of the gift." See also $\$ 1002$.

7. Id. $\$ 111(b)$. "The amount realized from the sale or other disposition of property shall be the sum of any money received plus the fair market value of the property (other than money) received." In some cases the "value" of property as of March 1, 1913 must be ascertained to establish a basis for computing gain or loss on a subsequent sale. Here the statute (INT. REv. Cone $\S 113(a)(14)$ ) provides that the basis for determining gain is "fair market value" and that in determining such value for stock "due regard shall be given to the fair market value of the assets of the corporation as of that date." Reference is made simply to "fair market value" in $\$ 112(\mathrm{c}), \S 112(\mathrm{~d})(2)$, and $\S 113(\mathrm{a})(6)$, dealing with the worth of property exchanged; $\$ 113(a)(2)$, dealing with the worth of property received by gift; and $\$ 113(\mathrm{a})(5)$, dealing with the worth of property received by bequest.

8. U.S. Treas. Reg. 105, $\$ 81.10$ (a) (1944): "The value of every item of property includible in the gross estate is the fair market value thereof ..."

9. Id. $\$ 81.10$ (c) (1944): "If actual sales or bona fide bid and asked prices are not available, then, in the case of corporate or other bonds, the value is to be arrived at by giving consideration to the soundness of the security, the interest yield, the date of maturity, and other relevant factors, and, in the case of shares of stock, upon the basis of the company's net worth, earning power, dividend-paying capacity, and all other relevant factors having a bearing upon the value of the stock."

10. Id. $\$ 81.10$ (c) (1944): "In cases in which it is established that the value per bond or share of any security determined on the basis of selling or bid and asked prices as herein provided does not reflect the fair market value thereof, then some reasonable modification of such basis or other relevant facts and elements of value shall be considered in determining fair market value." 
ing buyer would pay to a willing seller." II Absolute formulae based on mortality tables are established to fix the dollar equivalents of annuity, life, remainder and reversionary interests. ${ }^{12}$ In general, the gift tax regulations are similar. ${ }^{13}$ Regulations respecting "fair market value" for income tax purposes invite equally speculative appraisals of "value." 14

The clarity of current standards of value is not increased by the frequent use of the phrase that "value" is what a willing buyer would pay to a willing seller for the property, each having a reasonable familiarity with all the facts. The courts in practice have frequently rejected the theory. ${ }^{15}$ If there are actual sellers and buyers, the prices set obviously do control. If there are none, a substitute standard must be established. If no "value" referable to a market actually exists, we do not promote analysis of the issue-selection of a substitute standard -by developing the fiction that we are looking for a "market value" where it is clear that none exists. What we are looking for is a substitute for "market value." In practice, the substitute is established by review of all "relevant factors."

Thus, the search for a standard for transmuting property into dollar equivalents for tax purposes proceeds from generality to generality without enlightenment; from "value" to "fair market value" to "what a willing buyer would pay a willing seller" to all "relevant factors." In the absence of information as to what is "relevant" there are in fact no standards-excepting the formulae restricting market price of stocks and use of mortality tables-to control the establishment of dollar equivalents for Federal tax purposes.

The reasons for the Commissioner's failure to be more specific will be discussed hereafter. Let us first see what has happened and is happening under current treatment of the valuation problem. The discussion will center principally on valuation of stock with respect to which no sales data are available. Space limitations obviously forbid

11. Id. $\$ 81.10$ (d), (e), (f) and (g) (1944), See also Robertson v. Routzahn, 75 F.2d 537, 539 (6th Cir. 1935) and cases cited: "Fair market value is the price in money or its equivalent that the property will bring at a voluntary sale to a willing buyer, both the seller and buyer having adequate knowledge of the material facts affecting the value."

12. Id. $\$ 81.10$ (i) (1944). The accomplishments of the Regulations in fixing an administratively feasible and generally equitable method of valuing annuities, life, remainder and reversionary interests have been substantial and have been approved. The leading case on the subject is Commissioner v. Marshall, 125 F.2d 943 (2d Cir. 1942).

13. U.S. Treas. Reg. 108, $\$ 86.19$ (1939).

14. See U.S. Treas. Reg. 111, \$29.111-1 (1941), reciting that "fair market value" is a question of fact. $\$ \$ 29.112$ (c) $-1,29.113$ (a) (6) -1 , and 29.113 (a) (5)-1 (1944) refer to "fair market value" without further definition.

15. For example, the courts have sustained claims of a taxpayer that a large block of stock should be valued at a lesser price than small holdings because dumping of the stock would depress the market. See notes 75 to 77 and text, infra. 
a discussion of all aspects of valuation; valuation of such stock is relatively frequent; and progress in solving the general problem of valuation may best be attained step by step, through weighing the merits and demerits of the present system as manifested in a limited area.

\section{Current Valuation of Stocks Having No Market Price}

The technique of trial and decision. It requires little citation of authority to support the conclusion that "value" is a "question of fact," ${ }^{16}$ and it is elementary that the conclusions of the Tax Court ${ }^{17}$ on questions of fact are binding on the appellate courts unless clearly erroneous. ${ }^{18}$ The Tax Court is thus given almost unparalleled discretion to determine-case by case-what standards shall be followed for estimating dollar equivalents. In the absence of any direction by Congress or the Commissioner as to how they should go about finding dollar equivalents, it might be hoped that it would proceed to establish a standard by judicial inclusion and exclusion. The Tax Court does not do so.

A fairly primitive approach to the problem is illustrated in Moses Mosler, ${ }^{19}$ in which the Board of Tax Appeals encompassed its entire decision in the following language:

The Commissioner determined a deficiency of $\$ 37,841.80$ in estate tax. The petitioners filed their petition for a redetermination of such deficiency alleging that the respondent erroneously increased the value of 3,600 shares of common stock of the Mosler Safe Co. owned by decedent.

16. See cases cited at note 1 , supra.

17. The valuation question is most often presented to the Tax Court (formerly the Board of Tax Appeals) upon petition for review of a determination of a deficiency by the Commissioner. INT. REv. CODE $\$ 272(a)(1)$. Occasionally the tax is paid and suit is brought in the District Court or the Court of Claims to recover the tax. 28 U.S.C. $\$ \$ 1340,1346$ (1948). The comments hereafter made respecting the Tax Court should be understood to include the actions of the District Court and the Court of Claims acting in valuation matters. Also, a uniform terminology referring to the Tax Court is used, although many of the decisions here discussed were made by the Board of Tax Appeals, predecessor to the Tax Court.

18. The decisions of the Tax Court were given an extraordinary degree of finality in Dobson v. Commissioner, 320 U.S. 489 (1943), which was followed by John Kelley Co. v. Commissioner, 326 U.S. 521 (1945). The doctrine has been qualified by the 1948 amendments to INT. REv. CoDE $\$ 1141$. Since the amendment, it has been held that an appellate court may reverse the decisions of the Tax Court when it appears that they are "clearly erroneous," thus substituting this standard for the more general rule that administrative findings of fact should not be disturbed where supported by substantial evidence. Kohl v. Commissioner, 170 F.2d 531 (8th Cir. 1948) ; WrightBernet, Inc. v. Commissioner, 172 F.2d 343 (6th Cir. 1949). As to the general scope of judicial review in valuation cases before the statute, see Elmhurst Cemetery Co. v. Commissioner 300 U.S. 37. 39 (1937), in which the Supreme Court said that the reversal of the Tax Court by the Circuit Court of Appeals "amounted to an unwarranted substitution of the Court's judgment concerning facts for that of the Board. There was substantial evidence, as appears above, to support the latter's conclusion and in such circumstances this must be accepted."

19. 16 B.T.A. 762 (1929). See also Catherine E. Richardson, 1 B.T.A. 1196 (1925); Marie H. Kelly, 15 B.T.A. 624 (1929). 
The petitioners are executors and executrices of the estate of Moses Mosler, deceased, with their principal office in New York, N. Y. Moses Mosler, the decedent, died January 18, 1922. At the time of his death he owned 3,600 shares of the common stock of the Mosler Safe Co. The fair market value of such stock at the date of death of said decedent was $\$ 783.75$ per share.

Twenty years later, the approach was scarcely more sophisticated and certainly no more enlightening. In Martha A. Allison, ${ }^{20}$ the financial history of the company with respect to earnings, dividends and asset value was set forth in the findings of fact. The complete opinion on the valuation question follows:

One of the contested issues relates to the fair market value of the 99 shares of the common stock of the Wilkinsburg Bank owned by the decedent. . . . We have set forth the evidentiary facts in our findings of fact. Upon consideration of all the factors bearing upon the value of unlisted shares, where no sales have taken place at or approximately near the critical date, we conclude the fair market value of the shares in question was $\$ 45$ per share and have so found as a fact.

Nor are some of the current decisions of the District Court more enlightening. In Vereen $v$. Allen ${ }^{21}$ the complete rationale of the court was expressed as follows:

I find the fair market value of said stocks and bonds, as of the date of decedent's death, to be as follows: Moultrie Banking Co., $\$ 200$ per share; Moultrie Cotton Mills, $\$ 105$ per share; Riverside Mfg. Company, $\$ 150$ per share; Moultrie Grocery Company, $\$ 100$ per share. Moultrie Hotel Corporation bonds, $25 \%$ of their par value.

The brevity of these cases is not representative of the valuation process. Most of the decisions are longer; some of them are volum-

20. P-H 1946 T.C. MEM. Dec. I 46,273 (1946). In Mary E. Cook, 9 T.C. 563 (1947) the question at issue was the valuation of stock in a newspaper company. The decision was reached in the following terms: "The-stock was closely held at all times and there are no available records of any sales thereof at or near the valuation dates. The petitioner produced two witnesses, experienced dealers in securities, who undertook to value the shares on the basis of the information available to them. They did not have before them and did not take into consideration the business or financial condition of the issuing company and its earnings. Based on the evidence as a whole, we find that the shares in question had a value of $\$ 75$ each on December 10, 1941 and on May 29, 1942."

21. 75 F. Supp. 406, 407 (D. Ga. 1947). The decisions of the appellate courts are often equally unenlightening. For example, the decision in Estate of Warren $H$. Poley v. Commissioner, 166 F.2d 434 (3d Cir. 1948) states simply: "The questions here involve the valuation by the Tax Court of certain shares of estate stock and failure of that court to apply the blockage rule to the problem of the value of the shares. It is not our function in this type of case to substitute our conclusions and inferences for those of the Tax Court. The facts and circumstances furnish a reasonable basis for the conclusions that body reached." 
inous. $^{22}$ Few are more enlightening. The usual approach is to include either in the findings of fact or the opinion a resume of at least a portion of the evidence. Frequently the opinion will state that evidence on a certain point-book value, net asset value, earnings, balance sheets and various items relating to business prospects-is relevant but not controlling. For want of more definitive information these comments are listed in standard compilations to indicate the type of matters that will be considered. ${ }^{23}$ From the summary of the evidence and the general comments on it, each reader decides for himself what the motivation of the court might have been. In most cases, the ultimate conclusion as to value is prefaced by a statement that the valuation is based on all the evidence and a consideration of all relevant factors, a recital impelled by the requirement of the regulations and the insistence of the courts that all relevant factors must be considered. ${ }^{24}$ Occasionally, the absence of measurable connection between the evidence received and the result reached is frankly stated. ${ }^{\mathbf{2 5}}$

The shortcomings of this procedure can best be illustrated by a hypothetical counsel who appeals to the Tax Court to establish the "value," on behalf of each of several clients, of stock of the same general nature for which a general market is not available. He introduces evidence of all factors which he thinks might be relevant but thinks it best to address especial attention to the factor most likely to be con-

22. See, e.g. James Couzens, 11 B.T.A. 1040 (1928).

23. As indicated in note 2 , supra.

24. This process can be seen in almost all of the cases cited in this article. The current approach of the Tax Court to the problem is stated in Elizabeth Bowen, P-H 1948 TC MEN. DEC. $\{48,094$ (1948): "It has been held to be error, as a matter of law, to base the estimate of value for purposes of fair market value upon one factor to the exclusion of other relevant factors. [Citing cases.] In Worcester County Trust Co. et al. v. Commissioner, 134 F.2d 578 (1st Cir. 1943), the court disapproved the method there applied of basing value on the one factor of a multiple of earnings, and we think that respondent's proposed value runs athwart the adverse ruling in the Worcester County Trust Company case. It is based upon a multiple of one year's dividends, and little if any weight is given to any other factors. Alexander Smith and Sons paid dividends totaling $\$ 400$ per share in 1941 . The average dividends paid over a seven-year period was $\$ 250$ per share. In 1942 , dividends totaled $\$ 250$ per share. In 1941, earnings were unusually high, the highest since 1928, with the exception of the year 1929. A representative period of earnings and dividends should be considered so that the estimate of value may not be distorted by the abnormalities of one year. [Citing cases.] Respondent has given too little weight to the Company's record of past earnings, past dividends, the cyclical nature of the industry, prospective earnings, and other factors. Just as earnings are only one of the elements to be considered in determining the value of stock, so dividends are only one of the factors." See also Texas-Empire Pipe Line Co. v. Commissioner, 127 F.2d 220 (10th Cir. 1942).

25. Note for example, Daniel Guggenheim, 39 B.T.A. 251, 293 (1939): "The basic facts are shown in our findings. Some of the evidence on which they are based will be referred to briefly; but no attempt will be made to make a complete summary of all the evidence or to assign to every fact its precise relation to the conclusion reached". See also Daniel P. Hoover, 38 B.T.A. 387, 390 (1938); James Couzens, 11 B.T.A. 1040, 1162-1163 (1928) ; Ann L. Keenan, 4 B.T.A. 1232 (1926); Marie H. Kelly, 15 B.T.A. 624 (1929); Charles E. Kimball, P-H 1946 TC MEM. DEC. II 46,268 (1946). For similar comments, see cases cited at note 36 infra. 
trolling. Since it seems reasonable that the net asset value of the corporation must be a starting point for a valuation, he first emphasizes that factor. He is surprised to learn from the Tax Court that the real solution to his valuation problem lies in a capitalization of the earnings of the company. ${ }^{26}$ Profiting by his experience, he directs primary attention in his next case to the earnings of the corporation. He then discovers that the net asset value of the corporation is the proper basis for ascertaining the "value" of its stock. ${ }^{27}$ In his next case, he emphasizes these two factors and then finds the decision reaching a result which accords with book value, which may or may not be synonymous with actual net asset value. ${ }^{28}$ In his next trip to the Tax Court he emphasizes all of the foregoing factors and discovers that the value is established by reference to occasional and isolated sales, ${ }^{29}$ or offers to purchase. $^{30}$ By now he is convinced that:

Cases can be found in which primary or exclusive emphasis has been properly placed upon one or the other of almost every factor which the regulations state are to be considered in the determination of fair market value. ${ }^{31}$

Accordingly, he resolves to leave no stone unturned in preparation for his last case. He investigates the fiscal and merchandising history of the corporation issuing the stock. He compiles information respecting the earnings, dividends and balance sheets of the company for many prior years. $\mathrm{He}$ investigates the percentage of earnings paid out in dividends and such occasional sales of the stock as there may have been in past years. He reviews the book value of the assets and the stock; examines the depreciation rates of the company; has valuation engineers make a survey of the nature and dollar equivalent of tangible assets of the company, as well as its intangibles including good will; and studies the financial status of the corporation, especially with respect

26. Robertson v. Routzahn, 75 F.2d 537, 539 (6th Cir. 1935): "The market value of shares of stock, in the absence of a showing that the future will bring a change in the profits of the company, is largely determined by the earnings in the previous year"; Commissioner v. Johnson, 51 F.2d 1075 (6th Cir. 1931); Blackard v. Jones, 62 F. Supp. 234 (W.D. Okla. 1944); Wishon v. Anglim, 42 F. Supp. 359 (N.D. Cal. 1941); and Rheinstrom v. Willcutts, 26 F. Supp. 306 (D. Minn. 1938).

27. In re Nathan's Estate, 166 F.2d 422, 426 (9th Cir. 1948) : "The conclusion that under certain circumstances the value of stock in a closely held corporation which has never been sold to the public is to be ascertained solely on the basis of the corporation's net worth, is not without precedent." [Citing cases.] See also Patterson v. Commissioner, 42 F.2d 148 (2d Cir. 1930); A. S. Pendleton, 20 B.T.A. 618 (1930).

28. True v. U.S., 51 F. Supp. 720 (D. Wash. 1943); Frederick A. Koch, 28 B.T.A. 363 (1933).

29. Rogers v. Helvering, 107 F.2d 394 (2d Cir. 1939).

30. Manufacturers Paper Co. v. Commissioner, 89 F.2d 684 (2d Cir. 1937).

31. In re Nathan's Estate, 166 F.2d 422 (9th Cir. 1948). 
to bonded indebtedness, working capital, impairment of surplus, preferred stock, and the ratio of current assets to liabilities. He considers also the past, present and potential market for the product of the company, including business on the books; the past, present and potential competition of the company; the past, present and potential business outlook generally; the age, competence, salaries and state of health of the officers of the company; and present and potential plant capacity. He reflects also upon the percentage of total shares of the company represented by the stock to be valued and whether there are any restrictions upon sale of the stock. ${ }^{32}$ If he follows a suggestion recently made, he will conduct an investigation of that company equivalent to the investigation of the Securities and Exchange Commission, which frequently uses several investigators over a considerable space of time to ascertain the financial condition of a company which proposes refinancing in some form. ${ }^{33}$ Each of the foregoing factors will tend to add to, or detract from, the "value" of the stock. He will accordingly allocate to each of the factors a plus or minus "value," on a dollar basis. After weighing each of the factors individually, he will weigh the cumulative effect of the factors adding to or subtracting from the "value" of the stock. Ultimately, he will reach a dollar figure. Having done so, he will repeat the entire process for a representative number of other corporations in the same business, the stock of which is traded on the market. This will enable him to show comparative valuations between the stock to be valued and that traded in the open market. This factor is considered relevant in all cases and especially must be considered in estate tax cases under the requirements of Section $811(\mathrm{k}) .^{34}$ The study will also furnish comparatives to establish the proper rate for capitalization of earnings. ${ }^{35}$ Having piled guess on speculation and prediction upon estimate, he presumably will come out with that "value" which will best suit his clients' purpose while remaining at least potentially acceptable to the Tax Court.

The unpredictability of "value." The perplexities that beset the Commissioner, the taxpayers and the courts under the present valuation system need little elaboration. It is not merely that there is no

32. The following decisions are illustrative of one or more of the foregoing factors: James T. Hooper, 41 B.T.A. 114 (1940); Daniel P. Hoover, 38 B.T.A. 387 (1938); Grace S. Stebbins, 1 B.T.A. 1157 (1925); John B. Bryan, P-H 1943 T.C. MEM. DEC. I 43,208 (1943); Herbert L. Johnston, P-H 1943 TC MEM. DEC. I 43,296 (1943); Rathbun Fuller, P-H 1942 TC MEM. DEC. If 42,442 (1942); John B. Waterman P-H 1941 TC MEN. DEc. $\llbracket 41,551$ (1941). See also MERTENS and PAUt, $o p$. cit. supra note 2 , and cases cited.

33. See Hamburg, Tax Valuation of Real Estate, Stock, and Good Will, 6 Proc. of INST. on FED. TAX'N. 145, 158 (1948).

34. Quoted at note 5 supra.

35. As to capitalization of earnings, see notes 69 to 71 infra, and text. 
guide to a negotiated settlement of cases where the Commissioner and the taxpayer may disagree; but that there is never a case involving close held stock where the Commissioner, the taxpayer, the Tax Court or the appellate courts have a standard for determining either the relevance of factors or the weight to be accorded any of them. It is not only that the taxpayer must introduce evidence concerning every potentially relevant factor; but also that the Tax Court must set out in each case a result for that case alone: a ticket "good for this day and train only." Thus, to an extraordinary degree, not only does the Tax Court-not the Congress-make the law, but it makes a separate rule for each case as it is presented.

The difficulties of ascertaining "value" in the absence of any standard have not gone unlamented. Occasional Tax Court decisions have stressed that a result was reached only because the issue of "value" had to be resolved somehow. ${ }^{36}$ Appellate courts have reiterated that a finding of "value" in this context represents little more than conjecture. ${ }^{37}$ In some cases, evidence has been rejected because it was too specula-

36. For example, in Amy H. DuPuy, 9 T.C. 276, 284 (1947) it was said: "The evidence does not lead irresistably to any amount as the obviously correct value, but, since a finding of a precise amount must be made, the Court has concluded, after considering all of the evidence in the case, that the value of the stock on the valuation dates was $\$ 1,300$ per share." See also James T. Hooper 41 B.T.A. 114, 130 (1940); Daniel P. Hoover, 38 B.T.A. 387, 398 (1938); Henry Walters, 35 B.T.A. 259, 263 (1937).

There has, in fact, been no patentable improvement in the law of valuation for the last twenty years. The term "value" is just as elusive today as it was in 1928, when the Board said in James Couzens, 11 B.T.A. 1040, 1165 (1928) : "The conflict of opinion, however, and the diversity of reasoning by which such opinions were arrived at indicate that the problem of valuation... has not yet been developed so far that any particular method of reasoning in respect of it is authoritative or any particular class of persons may be recognized as experts. There is likewise no method of arriving at such value which, so far as our research and briefs of counsel show, has been established in the law as controlling. The facts and circumstances must be fully known in each case together with any available evidence of their interrelation and importance, and from this in its entirety the independent judgment of the Board must be derived." See also similar comments in cases cited at note 25 supra.

37. See, for example, the decision in Commissioner v. Marshall, 125 F.2d 493, 946 (2d Cir. 1942) where Judge Frank said: "The truth is that it has different meanings in different contexts, even in the restricted field of 'tax law.' And there, as almost always, 'value' involyes a conjecture, a guess, a prediction, a prophecy.", In an earlier case the same circuit court, speaking through Judge Learned Hand, resolved the valuation question in Elverson Corporation v. Helvering, $122 \mathrm{~F}$. 2d 295, 298 (2d Cir. 1941) as follows: "The taxpayer called four experts, the Commissioner two, and the Board appraised the shares at the same value as that given by the lower of the Commissioner's experts, though not for the same reasons as he. The value of the shares depended, as all value does, upon their future earning power, obviously a highly speculative matter as to which no forecast is much better than a guess. We cannot say that the figure taken was so unreasonable that we must upset it; an attempt by us to fix another would not be likely to strike nearer the unattainable mark." See also Andrews v. Commissioner, 135 F.2d 314, 317 (2d Cir. 1943); Guggenheim v. Helvering, 117 F.2d 469, 474 (2d Cir. 1941); Patterson v. Commissioner, 42 F.2d 148, 149 (2d Cir. 1930). See also the reference in Helvering v. Safe Deposit and Trust Co. of Baltimore, 316 U.S. 56, 66 (1942) to value as an "approximation derived from the evaluation of elements not easily measured." 
tive, ${ }^{88}$ though it is difficult to see why speculative evidence should be irrelevant in reaching a speculative result. ${ }^{39}$

It should be noted also that the absence of any standard necessarily makes for uneven administration of the law by the various offices of the Bureau, particularly in the income tax cases where operations are decentralized. Even where administration is centralized in Washington, the decision of the agent in the field must be accorded great weight in a matter so completely intuitional as valuation. Uniformity in administration suffers accordingly.

Moreover, any decision which cannot be rationalized is more than usually unpalatable to the loser. This is likely to be particularly true where a taxpayer loses a case against the Commissioner. If giving the appearance of justice is an important adjunct to the rendering of justice itself, the present valuation process leaves much to be desired. The acceptance by the taxpayer of the decisions of the Commissioner and the courts on valuation questions may best be described as an involuntary act of faith.

In addition, complaints are not infrequently made by the Tax Court that insufficient evidence has been presented for its consideration. ${ }^{40}$ The risk of the taxpayer in presenting evidence on anything less than all relevant factors has already been noted. Where all relevant factors must be considered, and there is no standard of relevance, a trial is likely to become time consuming for the court, exhausting to the ingenuity and patience of counsel, and disastrous to the pocketbooks of the litigants. In these circumstances, the suggestion that the investigation of value be made similar to that made by the Securities and Exchange Commission is not extravagant. The simple fact is that while the sums involved will seldom justify this kind of investigation, the present operation of the valuation process contemplates that such an investigation is feasible in all cases.

The presumption that the valuation of the Commissioner is correct. In the absence of any standards for valuation, the Commissioner obviously must make a determination on a primarily intuitive basisessentially, what is fair-in each case. When such a decision is made,

38. Daniel P. Hoover, 38 B.T.A. 387 (1938) ; Reba S. Buchanan, P-H 1941 TC Mex. Dec. II 41,091 (1941); Estate of Jacob Fish, 1 B.T.A. 882 (1925).

39. See Guggenheim v. Helvering, note 36 supra, at 474, where shares were to be valued in a corporation whose affairs were especially subject to the hazard of specific delays and risks: ". . it is no more speculative to appraise the proper discounts for the delays, the risks and the liabilities involved than to appraise the shares themselves."

40. Charles W. Ballard, 25 B.T.A. 591 (1932) ; Edward E. Hanscom, 24 B.T.A. 173 (1931); Helen K. Bromley, 16 B.T.A. 1322 (1929). 
it is presumed to be correct. ${ }^{41}$ Whatever may be the merits of the presumption in matters concerning objective proof such as receipts and disbursements of the taxpayer, the value of the presumption loses weight in a case where a subjective judgment is so patently involved. Yet reference to the presumption has frequently been made by the trial and appellate courts. ${ }^{42}$ The difficulty of the taxpayer may be demonstrated by an example. In Nathan Lamport ${ }^{43}$ the taxpayer claimed that in reaching an asset valuation figure the Commissioner failed to make allowance for a mortgage against some of the assets valued. The Commissioner did not state the basis for his determination, which was supported by the presumption of correctness. Indeed, it is very doubtful that he could have been compelled to disclose his basis. ${ }^{44}$ The Board of Tax Appeals sustained the Commissioner on the ground that they could not tell what consideration moved the Commissioner and that for all the record showed the fair market value may have been in excess of that set by him. ${ }^{45}$ Moreover, it would be unrealistic to

41. The United States Supreme Court recently insisted that the Tax Court take "into account the presumption supporting the Commissioner's ruling." Commissioner v. Heininger, 320 U.S. 467, 475 (1943). See also cases collected at 3 P.H 1949 FED. TAX SERv. I 23,361. Moreover, under INT. Rev. CODE $\$ 1119(\mathrm{a})$, the burden of proof in establishing the invalidity of any determination of the Commissioner is, with minor exceptions, on the taxpayer.

42. The principle was adopted by the Tax Court at an early date in valuation matters : Jacob Fish, 1 B.T.A. 882 (1925) ; Lucy H. Sturgess, 2 B.T.A. 69 (1925); Horace Delisser, 2 B.T.A. 102 (1925); James Couzens, 11 B.T.A. 1040 (1928); Albert J. Hopkins, 24 B.T.A. 805 (1931). Se also Brink v. United States, 20 F. Supp. 849 (D. Mass. 1937) ; J. K. McAlpine Land and Development Co. v. Commissioner, 126 F.2d 163 (9th Cir. 1942), and cases cited.

43. Nathan Lamport, 28 B.T.A. 862 (1933).

44. See United States v. Morgan, 313 U.S. 409 (1941), holding that there could be no cross-examination of the Secretary of Agriculture with respect to his process of decision in a rate case. This determination followed a hearing. Query whether the same result would be reached in a matter-such as assessment of a tax deficiencywhere no hearing is required and the action of the Commissioner is more administrative and less judicial. See also other cases cited note 54 infra.

45. Essentially the same principle has been stated elsewhere. In Victor Machris, P-H 1938 B.T.A. MEM. DEC. $\int 38,076$ (1938) it was said: "It is his determination that is in issue and not his method of making it. The petitioner is not relieved of the burden of showing the determination to be erroneous, even though the respondent may have proceeded upon a wrong theory or employed an incorrect method." See also Crowell v. Commissioner, 62 F.2d 51 (6th Cir. 1932); Rheinstrom v. Willcutts, 26 F. Supp. 306 (D. Minn. 1938) ; Charles J. O'Laughlin, 30 B.T.A. 1327 (1934) ; Edgar M. Carnrick, 21 B.T.A. 12 (1930). In cases where the taxpayer has relied on opinion evidence, such evidence frequently has been discarded and the decision based on the presumption. National Weeklies, Inc. v. Commissioner, 137 F.2d 39 (8th Cir. 1943) ; Gessell v. Commissioner, 41 F.2d 20 (7th Cir. 1930) ; A. S. Pendleton, 20 B.T.A. 618 (1930); Richard B. Messer, 27 B.T.A. 556 (1933); Helen K. Bromley, 16 B.T.A. 1322 (1929). In Rutud Mfg. Co. v. Commissioner, 45 F.2d 63, 65 (3d Cir. 1930)) modifying 15 B.T.A. 819 (1929), it was said: "No clear evidence was submitted from which it could be logically concluded that the redetermination was erroneous, and in the absence of such evidence. the decision of the Board must be affirmed on this point."

Moreover, the presumption of the Commissioner may sometimes be discarded, as in Mount v. Commissioner, 48 F.2d 550, 552 (2d Cir. 1931), where it was said: "There must be a limit beyond which the presumptive correctness of the Commissioner's determination may not be stretched in order to defeat a taxpayer." See also Sioux City Stockyards v. Commissioner, 59 F.2d 944 (8th Cir. 1932). It is some- 
assume that the Bureau, aware of the vigor with which claims for low valuations are pressed by taxpayers, does not at least occasionally rely on that "factor" which will result in a high valuation. An occasionaland possibly untrue-rumor is heard that in practice the Bureau resolves stock valuation problems where no market price is available by taking the higher of net asset value and capitalization of earnings.

Certainly the expert opinion of the Commissioner on "value" is entitled to some weight. But the weighting of the scales against the taxpayer here emphasizes the need for some objective standards against which the determination of the Commissioner-now almost completely subjective-may be measured. ${ }^{46}$ If, as has been suggested, valuation is ordinarily a compromise process, ${ }^{47}$ the ability of the taxpayer to negotiate may be unfairly hampered by the power of the Commissioner to rely on a presumption that his determination is correct, where there is no statutory standard by which his exercise of judgment can be measured.

To what extent decisions of the Commissioner and Tax Court are final. The proper scope of judicial review of administrative adjudications has given rise to more uncertainty than almost any other aspect of governmental administration. The question has been particularly acute since Dobson v. Commissioner, ${ }^{48}$ in which the Supreme Court directed that an unusual degree of finality be accorded decisions of the Tax Court, whether based on "law" or "fact." 49

The difficulties of judicial review of the valuations of the Commissioner are pronounced because the valuations must be based on "all relevant factors." Such a requirement invites vagueness on the part of the Commissioner. If he uses a figure equivalent to asset value, for example, the Tax Court or Circuit Court of Appeals may conclude that he did not consider "all relevant factors." 50 However, if the Com-

times said that the presumption ceases when evidence is introduced. True v. United States, 51 F. Supp. 720 (D. Wash. 1943). Under these circumstances the question of when the taxpayer has introduced sufficient evidence to overcome the presumption is always present and always unpredictable.

46. See PaUL, StUdIES IN FEDERAL TAXatron 162 (1937): "No one knows what the word 'value' means until he is told. The meaning is what the United States Government chooses it to mean . . . one thing if it is protecting investors, and another thing if it is taking their profits from them."

47. As suggested at 2 PaUl, Federal Estate and Gift Taxation 1220 (1942).

48. 320 U.S. 489 (1943).

49. See note 18 supra for a discussion of subsequent legislation on the subject.

50. See, e.g., Forbes v. Hassett, 124 F.2d 925 (1st Cir. 1941) ; Crowell v. Commissioner, 62 F.2d 51 (6th Cir. 1932) ; White and Wells Co. v. Commissioner, 50 F.2d 120 (2d Cir. 1931). See also Wishon v. Anglim, 42 F. Supp. 359, 361 (N.D. Cal. 1941), where the court referred to the Treasury Regulation that all relevant factors must be considered, and reversed the Commissioner in the following language: "The Commissioner's 'guess' as to value is not controlling here because he ignored the rule of the Treasury Department above quoted and based his appraisal wholly upon 'asset' or net value. It is stipulated that the asset value of Mrs. Wishon's stock at the date 
missioner adopts a figure which is arbitrary-in the sense that it is not referable to any theory or theories-it is obviously more difficult for the taxpayer to establish that no allowance was made for one factor or several factors. ${ }^{51}$ A premium is thus placed on the adoption of a dollar result unconnected with any standard of "value." In this connection, one practitioner has made a wry comparison between the Commissioner and the justice of the peace who never was reversed until he wrote an opinion. ${ }^{52}$ In fact, the scales are overweighted against a taxpayer confronted not only with the presumption that the Commissioner's valuation is correct, but also with a dollar valuation not referable to any specific standard. The effect of the present valuation proccess was aptly described in Patterson v. Commissioner ${ }^{53}$ where it was said:

Probably it is true that the holder of such shares must usually be content with the guess of the Commissioner, because when property is not sold on an open market where a number of buyers can establish its value, it will seldom be possible to contradict the first honest judgment formed.

The valuations of the Tax Court, when considered on appeal, stand in a stronger position than those of the Commissioner, its judgment in valuation cases normally being undisturbed. Presumably, being a fact finding tribunal, the Tax Court is not required to adopt any factor or combination of factors. Nevertheless, the Board is required to consider the factors, whether adopted or not. Here, too, there may be a tendency to seek refuge from judicial reversal in the standard recital that the conclusion is based on all relevant factors. In any event the writer has seen no decisions in which the Tax Court has admitted in terms that it has found one factor controlling, or that one or more factors have been ignored because they had no relevance to the valuation

of her death was $\$ 838.55$ per share. The Commissioner appraised it at $\$ 838.36$, a difference of 19 cents. The stipulated asset value of Mr. Wishon's stock was $\$ 1,023.95$, and the Commissioner's appraisal was in the identical amount."

51. This difficulty of the taxpayer is not, however, insuperable. In Patterson v. Commissioner, 42 F.2d 148 (2d Cir. 1930) where the Commissioner valued common stock at $\$ 16.36$, and the court said: "Had the Commissioner found the value at $\$ 16.30$, we think we could divine how he proceeded; for a valuation of the assets at $\$ 200,000$ would so result. Subtract the preferred stock, $\$ 37,000$, and the value of the common shares comes out at $\$ 16.30$. We cannot account for the added 6 cents, but the difference is unimportant." Cf. Elizabeth Bowen, P-H 1948 TC MEM. DEC. \ 48,094 (1948), where it was said: "It is generally recognized by the courts that unlisted stocks in close corporations lack marketability... Respondent's expert testified that he recognized that this factor should be considered in valuing the Smith Company stock, but we are unable to recognize any real consideration of that factor by the respondent." See also cases cited at note 61 infra respecting decisions of the Tax Court. (1945).

52. Van Dyke, Commissioner Unfair to Fair Market Value, 23 TAXEs 788 53. 42 F.2d 148, 149 (2d Cir. 1930). 
in question. Of course, under general administrative practice, the taxpayer would not be permitted to cross-examine the court concerning whether all factors were in fact considered and if so how much weight was given to this factor or that. ${ }^{54}$ Accordingly the requirement that "all relevant factors" must be considered avails him nothing insofar as a possible reversal is concerned. His primary hope is that he can show that the Tax Court was in error in refusing to apply, rather than consider, certain factors in reaching the result. Occasionally, as in In re Nathan's Estate ${ }^{55}$ courts have been reluctant to review the conclusions of the Tax Court on this basis. Other courts have looked through the standard recital that all relevant factors have been considered and have reversed the conclusion of the Tax Court, presumably on the theory that they were not considered properly. ${ }^{58}$

Since the findings of the Tax Court are conclusive if supported by evidence, and the regulations and case law require only that all factors be considered, the view of In re Nathan's Estate seems to be more logical. The dilemma which arises here is whether to repose almost unrestrained discretion in the Tax Court or to permit the appellate courts to substitute their views as to the proper method of establishing the dollar equivalents of property for federal tax purposes. It has been

54. United States v. Morgan, 313 U.S. 409 (1941); National Labor Relations Board v. Botany Worsted Mills, Inc., 106 F.2d 263 (3d Cir. 1939) ; Cupples Company Manufacturers v. National Labor Relations Board, 103 F.2d 953 (8th Cir. 1939); National Labor Relations Board v. Biles Coleman Lumber Co., 98 F.2d 16 (9th Cir. 1938). In Chicago, Burlington and Quincy Ry. Co. v. Babcock, 204 U.S. 585, 593 (1907), the court held that it was improper to examine the members of a tax assessing board as to their exercise of judgment in making an assessment: "This was wholly improper. In this respect the case does not differ from that of a jury or an umpire, if we assume that members of the Board are not entitled to the possibly higher immunities of a judge."

55. 166 F.2d 422, 428 (9th Cir. 1948) : "We are inclined to agree with respondent that petitioner, although alleging that the Tax Court 'failed to consider' pertinent evaluation factors, is in fact charging that the Tax Court 'failed to accept' certain criteria as being here determinative. The weight to be accorded the various evidentiary factors depends upon the facts of each case." See also Judge Huxman's dissent in Texas-Empire Pipe Line Co. v. Commissioner, 127 F.2d 220, 228 (10th Cir. 1942); Guggenheim v. Helvering, 117 F.2d 469, 473 (2d Cir. 1941).

56. Worcester County Trust Co. v. Commissioner, 134 F.2d 578 (1st Cir. 1943) ; Texas-Empire Pipe Line Co. v. Commissioner, 127 F.2d 220 (10th Cir. 1941); Newell v. Commissioner, 66 F.2d 103 (7th Cir. 1933). The determination of the Board of Tax Appeals was approved in Manufacturers Paper Co. v. Commissioner, $89 \mathrm{~F} .2 \mathrm{~d}$ 684,686 (2d Cir. 1937) where the Board set a value of $\$ 256,308.96$ for stock and an offer to buy the stock for $\$ 256,309.00$ had been made. The Board referred to the offer only as "entitled some weight." The court said: "The correspondence between this figure and the valuation adopted by the Board is so nearly exact that the inference is irresistible that their valuation was arrived at in this way. No other combination of figures appearing in the record could produce it." Note also the decision in Sue E. Holmes, 22 B.T.A. 757 (1931) where the Board expressly asserted nonreliance on the selling price of inactive stock, but judging from other decisions the Board would have found a higher value solely on basis of asset value and earnings. Reversal of Tax Court and Board decisions has been most general where specific theories are involved; e.g. see notes 75 to 77 and 84 to 88 infra and text, where blockage and transfer restrictions were concerned. The Board has also been reversed on the ground that the result was reached in an arbitrary and unfair manner. Foss v. Commissioner, 75 F.2d 326 (1st Cir. 1935). 
moted that this problem pervades the entire field of administrative law, including many of the decisions of the Tax Court in matters unrelated to valuation. The peculiar difficulty of the problem in this context arises from the almost complete absence of standards of any kind by which the actions of the Commissioner and the Tax Court can be measured on appeal.

Appellate review of Tax Court decisions presents still another difficulty. What happens when the appellate court concludes that the Tax Court has not given proper consideration to a "relevant factor"? The standard procedure is to return the case to the Tax Court for further consideration. ${ }^{57}$ However proper this may be in theory, it presents some difficulties in practice. The appellate courts have frequently admitted that valuation is an intuitional process. ${ }^{58}$ Nevertheless, in specific cases they may say in substance to the Tax Court: "Deduct something from your dollar result to allow for a transfer restriction on the stock." The response of the Tax Court might well be embodied in the following hypothetical reply: "We don't think there should be any deduction - as we said when the case was here beforebut of course you have the power to review and direct our decision. So we will deduct something, since you require it. Of course, you don't tell us how much, or even how we should approach the problem of setting a figure. We both understand that you can't do that because it is almost absolute conjecture. Do you think about $10 \%$ would be all right?"

It is clear that the next figure will not represent the conviction of the Tax Court-its determination has been rejected. In the absence of any standard for review, there is a considerable possibility that the computation will represent a sum thought to be sufficient to achieve an equality of discontent among the litigants and a probability of affirmance by the appellate court. In this type of problem, the suggestions made in a dissent by Judge Learned Hand appear persuasive:

The Tax Court has made its guess, and it is the only tribunal vested with authority to do so. We are now saying that there was no substantial evidence to support that guess, in which we are quite right; but we are sending the case back to make another guess, which in the nature of things we must know will have as little to rest upon as the first. That seems to me quite beyond our function; the fact that we should have ourselves fixed a lower

57. See, e.g., Andrews v. Commissioner, 135 F.2d 314 (2d Cir. 1943) ; Worcester County Trust Co. v. Commissioner, 134 F.2d 578 (1st Cir. 1943); Guggenhe1m v. Helvering, 117 F.2d 469, (2d Cir. 1941); Weber v. Rasquin, 101 F.2d 62 (2d Cir. 1939) ; Behles v. Commissioner, 87 F.2d 228 (7th Cir. 1937); Patterson v. Commissioner, 42 F.2d 148 (2d Cir. 1930).

58. See notes 36 to 39 sipra and text. 
price-I should also have done so-does not give us authority to compel the Tax Court to do so. ${ }^{59}$

However the problem may be resolved, the ultimate decision as to "value" under the current valuation process seems only remotely related to the basic problem of ascertaining what standards Congress had in mind for establishing dollar equivalents of property in Federal tax cases.

Summary of the problem. The deficiencies in the present valuation process are clear. The immediate cause for the present system of speculation and conjecture is not far to seek. It arises from the use of the word "value" as an "anodyne for the pains of reasoning" required to set out a measurable standard for establishing the dollar equivalent of property for Federal tax purposes. The term "value" means what the Commissioner and the courts choose it to mean. In effect we are saying that the Commissioner shall impose a fair tax in view of the nature of the property transmitted, but this assessment shall not be unreasonable; that the Tax Court may say that the determination is unreasonable; and that the appellate courts may review that decision. In practice the Commissioner does not state the reasons for his determination; the Tax Court in review does not state its reasons, but expresses a dollar result after consideration of "all relevant factors"; the appellate courts usually rely on the Tax Court decisions but occasionally reverse on the ground that weight should or should not be given to a specified factor. It is, under law, a conspiracy of silence. In our anxiety to permit "play in the joints" in Federal tax valuations, we have created a system which has no joints because it has so little structure.

While the valuation process is an example of what Justice Rutledge has described as administrative fog, rather than administrative expertise, the fog is not self induced. It arises neither from administrative nor judicial incompetence. In this area, Congress has not merely delegated to the Commissioner and the courts the power to interpret Congressional directions as to the proper standards for establishing dollar equivalents for property in tax computations, but has commanded the Commissioner and the courts to establish such standards without even the most general directions. It is not surprising that the decisions have been unpredictable. Congress has never spoken on the subject, except in terms of "value."

59. Andrews v. Commissioner, 135 F.2d 314, 319 (2d Cir. 1943). 


\section{Proposed Solution}

Two preliminary observations should be made in the study of a proposal to improve the valuation process. First, the deficiencies which have been noted in the system are not peculiar to a determination of "value." It has hitherto been noted that uncertainty is evident in many tax problems, where wide latitude is given to the Tax Court to interpret Congressional directions which are necessarily stated in general terms. It has been noted also that this is particularly true in all cases involving a resolution of so-called questions of fact. The last twenty years have happily witnessed an awakening sense of realism among those who once believed that law could be made so definite and certain that administrative and judicial interpretation would be required only in the narrowest of limits. The appeal for "a government of laws and not of men" is seldom heard. There are real dangers in trying to set too many legislative standards for too many things. This should not, however, deter us from setting firm and fixed standards under which specified conduct will have a specified result where experience has demonstrated a breakdown of a purely intuitive approach to such a problem as the computation of Federal taxes.

Second, no proposal to rationalize the valuation process should proceed without a review of the merits claimed for the present procedure. The system seeks its ultimate justification in the fact that "relevant factors"-management competence, asset value, business prospects and all the others-may in fact tend to increase or decrease the worth of close held stock to the owner or a potential buyer. While the process of weighting the factors is admittedly speculative, it is apparently assumed that a fair and equitable result may be reached only by use of intuitive judgment after considering all the factors. It is this assumption which lies behind the frequent assertions of the courts that "value" is a matter of fact, not of formula. ${ }^{60}$ The observation has force, but it does not tell the whole story. It would be futile to seek a formula which would in all cases establish dollar equivalents for property as a simple arithmetical computation; the difficulties of establishing the dollar equivalent of real estate or personal property demonstrate the need for the exercise of some intuition by the administrators and the courts. What we ought to try to do is reduce the area of unpredictability so far as may be consistent with the common understanding of fair treatment for the taxpayer. The first portion of this article has been devoted to reducing the romantic generalities about the desirability of intuitive judgments to a specific study of the actual technique of trial and deci-

60. See note 1 supra. 
sion in cases involving valuation of stock which has no market price. If experience shows that fair and workable standards can be set in that area attention may thereupon be directed to creating standards to establish a dollar equivalent for other types of property. It is submitted that the demonstrated deficiencies of the valuation process can be alleviated.

Two steps should now be taken to improve the current valuation process :

1. All reference in the regulations to "all relevant factors" should be stricken.

2. A specific formula for the valuation of close held stock should be adopted, based on the asset value of the issuing corporation.

"All relevant factors." The first step in clarifying the valuation process should be to eliminate all reference in the regulations to "all relevant factors." This should be done not only with respect to valuation of stock which has no market price, but all other property as well. The requirement for consideration of "all relevant factors" has been interpreted in practice to mean that the decision shall not be placed on any specific factors. It thus becomes an instrument for concealing, rather than expressing, thought. As a result, the Commissioner and the courts avoid explaining exactly how they reached their respective decisions. It may be conceded that the decisions will always be intuitive in part and not subject to rational analysis. But the construction of case law on the subject is not going to progress until the courts fully express their reasons for decision to the extent that they can be articulated. $^{61}$

Elimination of the requirement that "all relevant factors" be considered does not mean that any directive need be substituted for it except in cases where a specific formula is found desirable. Presumably it is the present intention of Congress that the Tax Court and the appellate courts must conscientiously study the record and consider all the evidence in reaching a result. Consonant with the statutes and decisions relating to Federal tax determinations, that result presumably should be rejected on appeal only if clearly erroneous on the facts ${ }^{82}$ or if the valuation involved an "error of law." Where the Tax Court has made an improper valuation in a specific case, it is immaterial whether the result be attacked as an error of law (in that an improper standard of valuation is used) or as clearly erroneous on the evidence (because

61. For an example of a more rational decision than those of the Tax Court in the valuation field see Vale v. DuPont, 37 Del. 254, 182 Atl. 668 (1936).

62. See note 18 supra. 
evidence considered by the appellate court to be compelling was ignored by the Tax Court). In either event there is ample opportunity for judicial review, if the reviewing court is prepared to specifically find error of law or an otherwise clearly erroneous result. Certainly no useful purpose is served at present by the conclusion of appellate courts that the Tax Court has not considered a specific factor, when they mean that it has not applied the factor.

A specific standard for valuation of stock. It is suggested that the statutes and regulations respecting the valuation of close held stock for Federal tax purposes remain unchanged in cases where an actual market is available. Such prices are ascertained by market quotations, or (in the case of unlisted stock) are based on sales, bids or offers in arms length transactions at a time reasonably proximate to the valuation date. Thus the initial investigation of the Commissioner and the Tax Court is, and should continue to be, addressed to market price. If a market price based on such data can not be determined, the Commissioner and the Tax Court should so state.

However, the foregoing discussion indicates that regulations with respect to valuation for income, estate and gift tax purposes are inadequate in cases where no market price can be established. They should be amended to provide that the dollar equivalent for close held stock shall be established by computing the net dollar equivalent of the assets of the corporation, ${ }^{63}$ including good will and "going concern" value of the corporation in any cases where it is demonstrated that such value exists. The total sum should be divided by the total number of shares outstanding to reach the dollar equivalent of each share of stock for Federal tax purposes. Where different classes of stock are issued, the percentages of net worth to be assigned to each should be determined upon a reasonable basis in the discretion of the Tax Court, subject to the usual review.

Under this formula, the imperative need for the exercise of ordinary judgment by a fact finding body in any valuation matter would be recognized. Ample room for the exercise of discretion exists with respect to the valuation of the assets. This is particularly true of the valuation of good will. Flexibility of the formula would be insured by a clause authorizing computation of value on a reasonable modification of the formula where the use of the formula would result in injustice

63. The net dollar equivalent would be the market-not book-value of the assets. Occasionally, as in DuPont v. Deputy, 26 F. Supp. 773 (D. Del. 1939), claim has been made that the capital gain taxes payable on any sale of the assets should also be deducted, as well as the cost of disposition. Since actual disposition is not contemplated-the asset value being taken only for the purpose of computing the dollar equivalent for the stock-no deduction for these items should be permitted. Computation of good will and going concern value is considered in the following section of this article. 
to the parties. Such clause is currently included in the regulations respecting stocks having a "value" ascertainable through market price. ${ }^{64}$

Theory of the proposed formula. The current confusion and uncertainty in valuing stock which has no market price results in a large measure from administrative and judicial attempts to ascertain what the market price of such stock would have been had there been a market -what Judge Frank has described as "What-you-could-have-gotfor-it-in-money-if you-had-sold-it." The problems hereafter discussed concerning the effect of minority stock holdings, blockage, limited market for close held stock, values in comparative companies and contractual restrictions on the sale of stock, accordingly must be resolved under the present practice, since they are all "relevant factors" in determining market value. These factors, combined with the usual speculation respecting the inherent ability of the corporation to make money under present and projected business conditions, are the grist from which the present valuation decisions are ground.

The proposed theory seeks to channel the investigation of value into at least relatively narrow limits; the net asset value of the corporation. This substitutes a relatively fixed objective for pursuit of the will-o'-the-wisp of market price in the absence of a market. The result will be a reasonable approximation of "value," just as "value" based on stock market quotations (which may be unduly inflated or deflated) represents an approximation. ${ }^{65}$

\section{Operation OF the Formula}

Current use of asset value. The use of asset value as a measure for the tax is dictated by experience and convenience. Net asset value has always been considered a major factor in the valuation of close held stock. On many occasions asset values alone apparently have in fact been adopted as the measure of "value," ${ }^{86}$ although it has been reiter-

64. The regulation is set out at note 10 supra.

65. See Paul, Studies in Federal Taxation 188, 194 (1937) for an extended analysis of the subject in which he concludes that stock market quotations do not represent a proper measure of "value" for tax purposes unless qualified by other relevant factors. In Strong v. Rogers, 72 F.2d 455 (3d Cir. 1934) the court reduced a valuation below the market quotation on the theory that a well informed buyer would never have paid the stock market price.

66. Bank of California v. Commissioner, 133 F.2d 428 (9th Cir. 1943) ; Patterson v. Commissioner, 42 F.2d 148 (2d Cir. 1930) ; Forbes v. Hassett, 38 F. Supp. 62 (D. Mass. 1941); Henry E. Huntingdon, 36 B.T.A. 698 (1937); Frischkorn Development Co., 30 B.T.A. 8 (1934); Melville Hanscom, 24 B.T.A. 173 (1931); P. C. Pendleton, 20 B.T.A. 618 (1930); George F. Milton, 17 B.T.A. 380 (1929); Robert L. Holt, 14 B.T.A. 564 (1928); David Weingarten, 13 B.T.A. 249 (1928); American Trust Co., 13 B.T.A. 105 (1928) ; Anthracite Trust Co., 3 B.T.A. 486 (1926); George H. Burr, P-H 1945 TC MEM. DEC. I 45,364 (1945) ; Estate of Hogan, P-H 1944 TC MEN. DEC. II 44,109 (1944). See also Hinkel v. Motter, 39 F.2d 159 (D. Kans. 1930) and Robert H. McNeil. 16 B.T.A. 479 (1929). In many cases asset 
ated that reliance solely on asset values is improper under the rule that "all relevant factors" must be considered. ${ }^{67}$ Occasionally litigants have agreed that asset value shall control stock valuations. ${ }^{68}$

Use of net asset value superior to capitalization of earnings. It has generally been accepted that a proper measure of the "value" of unlisted stock is to capitalize the earnings of the corporation. ${ }^{69}$ The use of asset valuation, however, seems more fair, because there is less opportunity for variation in results. Capitalization of earnings requires two bases. First, the Commissioner must select a period of time which will reasonably reflect average annual earnings, excluding abnormal years. Second, he must select a capitalization rate to be applied to the earnings. If the business is stable, the rate would normally be low; if the business is hazardous, the rate would normally be high. The selection of a reasonable period of earnings and a reasonable rate is extremely subjective, and no general rules respecting proper rates for various industries have been adopted. ${ }^{70}$ It is thus difficult to hold the Commissioner and the Tax Court even to a reasonably objective standard for establishing "value" under a capitalization of earnings formula. Accordingly, where capitalization of earnings are used, prediction becomes impossible. The use of net asset value, while also subjective in part, unquestionably has more certitude for the administrators, the taxpayers and the courts.

Ascertainment of good will and going concern value. In some cases, exceptional earnings demonstrate that the stock is worth substantially more to the holder than an aliquot percentage of the immediate and measurable assets. In such a case it is apparent that there may be a good will or going concern value in the corporation. Under

values are accepted where there is no other evidence. See 10A Mertens, LAw of FeDERAL InCOME TAXation 55 (1948) and cases cited.

The nearest approach Congress has taken toward establishing asset value as the standard for valuation of stock is in INT. REv. CODE \$113(a) (14), quoted supra note 6 , where the commissioner and the courts are admonished to consider the fair market value of the assets of the corporation as of March 1, 1913 in establishing the basis for computation of gain on stocks sold on and after that date.

67. Forbes v. Hassett, 124 F.2d 925 (1st Cir. 1942); Weber v. Rasquin, 101 F.2d 62 (2d Cir. 1939); Wishon v. Anglim, 42 F. Supp. 359 (N.D. Cal. 1941); DuPont v. Deputy, 26 F. Supp. 773 (D. Del. 1939) ; Margaret Russell Vail, P-H 1940 BTA MEN. DEC. I 40,431 (1940); Amy H. Du Puy, 9 T.C. 276 (1947); Mary A. Laird, 38 B.T.A. 926 (1938) ; George D. Harter Bank, 38 B.T.A. 387 (1938) ; Frank A. Cruickshank, 9 T.C. 162 (1947) ; Maurice H. Bob, P-H 1945 TC MeM. DeC. \ 45,195 (1945).

68. See for example, Estate of Pamelia D. Holland, 47 B.T.A. 807 (1942), modified on other grounds, 1 T.C. 564 (1943); Julius G. Day, 3 B.T.A. 942 (1926); Jacob Fish, 1 B.T.A. 882 (1925).

69. As indicated by note 9 supra, consideration of this "factor" is now specifically required under the estate tax Regulations. A number of cases are collected at 103 A.L.R. 955 (1936); 10A Mertens, The Law of Federal Incone Taxation 57-61 (1948) ; 2 Paul, Federal Estate and Gift Taxation 1287-1293 (1942).

70. Ibid. 
the formula this is added to the other asset values. Establishment of a dollar equivalent for good will partakes somewhat of the nature of capitalization of earnings; that is, under current practice normal earnings are allocated to the other assets and the balance of the earnings is capitalized to establish good will or going concern value. Thus the Commissioner, in valuing good will, must select a reasonable period to ascertain average annual earnings, and establish a reasonable rate by which those earnings are to be capitalized. Under the proposed formula, the Commissioner would make this type of a subjective valuation, subject to review by the Tax Court and the appellate court. It would be appropriate to limit his discretion by requiring him to adopt, by regulation, certain capitalization rates for specified businesses. In any event, as long as the value of all the other assets may be fixed within reasonable limits, the possibility of unfairness through use of an improper capitalization rate or an improper period of earnings is minimized under the general formula suggested.

It is not contemplated that the Commissioner shall attempt to establish a good will value unless the earnings of the corporation are abnormal. Indeed, the Board of Tax Appeals has refused to sustain valuations made by the Commissioner on such a basis. ${ }^{71}$ Accordingly, while the difficulties in determining the worth of good will are substantial, the proposed formula restricts such a valuation to the fullest extent possible. This may be contrasted with the present valuation process, where the valuation of good will is at least in theory a "relevant factor" which presumably must be weighed with "all other relevant factors" in every case.

Minority holdings of stock. It has been suggested by some courts that the use of asset value to establish the dollar equivalent of stocks without a market price is improper where the stocks to be valued represent a minority holding. This conclusion is reached on the basis that the stockholder has no power to compel the majority interests to liquidate the stock so that he may receive his proportionate share of the assets. ${ }^{72}$ No allowance for the factor is made by the formula. The problem is most frequently encountered in the estate tax case. There, it seems absurd to assume even that the heir will seek to dispose of the stock at once. If we must speculate as to his intention it seems reasonable to believe that his intention normally would be the same as that of the decedent, who is unlikely to have invested in it primarily

71. Central Consumers Wine and Liquor Co., 1 B.T.A. 1190 (1925); William H. Jackson Co., 2 B.T.A. 411 (1925).

72. See for example, Weber y. Rasquin, 101 F.2d 62 (2d Cir. 1939). Perhaps the best known case supporting this view is Laird v. Commissioner, 85 F.2d 598 (3d Cir. 1935). 
with a view to what he could obtain in a forced liquidation. ${ }^{73}$ And even if he did desire to liquidate, it is unreasonable to assume that he would seek liquidation against the wishes of his fellow stockholders. It is just as reasonable to assume that they would seek liquidation against his opposition and it is most probable-because normally the most advantageous financially - that all the stockholders would agree on any liquidation program. In either of the latter events, his minority interest would certainly constitute no bar to establishing a dollar equivalent for the stock on the basis of asset value. It is compounding speculation first to assume that he will want to liquidate and then to assume that he will be precluded from doing so by the opposition of the majority stockholders.

Effect of restricted market. Two further arguments have been advanced to qualify the proposed use of asset value as a formula. The first is that close held stock is harder to sell than listed stock, ${ }^{74}$ and the second is that the asset value formula makes no allowance for "blockage"-a term which normally describes a lowering of stock values concomitant with placing a large block of stock on the market. ${ }^{75}$ Neither factor would be given weight under the proposed formula.

Both of these factors are, as a matter of theory, irrelevant to an inquiry-under the proposed formula-unrelated to the sale price of the stock. Further, the rule respecting blockage is subject to the arguments-rejected by some courts-that property in the hands of a small owner is unjustly appraised at a higher figure than that of a large owner; that all shares are necessarily of equal value; and that certainty is abandoned for speculation. Some courts have refused to speculate on the blockage issue, and have declined to approve application of the theory on the ground that the restrictive effects of blockage have not been demonstrated. ${ }^{76}$ The rule in fact compels speculation to an excessive degree. An initial speculation results in the somewhat violent

73. Compare Justice Holmes' comment in International Harvester Co. of America v. Kentucky, 234 U.S. 216 (1914), that value "is a fact and generally is more or less easy to ascertain."

74. Cravens v. Welch, 10 F. Supp. 94 (S.D. Cal. 1935) ; Bourn v. McLaughlin, 19 F.2d 148 (N.D. Conn. 1927); Wood v. United States, 29 F. Supp. 853 (Ct.Cl. 1939); James P. Hooper. 41 B.T.A. 114 (1940); Elizabeth Bowen, P-H 1948 TC Mem. Dec. \ 48,094 (1948). Compare John B. Bryan, P-H 1943 TC MEM. Dec. \43,208 (1943) referring to a "ready though restricted market" among other members of the family.

75. The major cases so holding with respect to stock valuation generally are Helvering v. Maytag, 125 F.2d 55 (8th Cir. 1942); Helvering v. Safe Deposit and Trust Co. of Baltimore, 95 F.2d 806 (4th Cir. 1938); Laird v. Commissioner, 85 F.2d 598 (3d Cir. 1935); Daniel Guggenheim, 39 B.T.A. 251 (1939); Safe Deposit \& Trust Co., 35 B.T.A. 259 (1937); Jacobine Fuller, P-H 1942 TC MEM. DEC. \4 42,322 (1942).

76. Mott v. Commissioner, 139 F.2d 317 (6th Cir. 1943) ; Bull v. Smith, 119 F.2d 490 (2d Cir. 1941) ; Groff v. Smith, 34 F. Supp. 319 (D. Conn. 1940). See also James Couzens, 11 B.TA. 1040 (1928). Appellate courts have also refused to overrule con- 
presumption that the owner of close held stock intends to sell at all; a second, that he intends to dump it on the market rather than feed it in slowly over a period of time; ${ }^{77}$ and a third speculation seeks to measure the effect on the market if the first two conjectures are correct.

The use of comparatives. The estate tax statute now provides in substance that in establishing market value for close held stock the stock values of comparable companies shall be considered with all other relevant factors. ${ }^{78}$ Basically this amounts to no more than an admonition to the Tax Court and the Commissioner not to ignore evidence respecting this factor. ${ }^{79}$ Comparatives have been especially emphasized in cases involving stocks for investment companies ${ }^{80}$ and are given considerable emphasis in valuation of the stock of operating companies as well. ${ }^{81}$ In some cases before the statute was adopted, the factor was accorded fittle weight. ${ }^{82}$

In the interest of providing a more workable and equitable system of translating property into dollar equivalents for Federal tax purposes, this provision of the statute should be repealed. As in the case of any one of the "other relevant factors," comparatives furnish only the most speculative basis for a decision of the Tax Court. Under the present theory, every "relevant factor" is weighed with respect to the company issuing the stock to be valued. An informative comparison of that company with other companies is an exceptionally exhausting and highly speculative process. To illustrate, one company may have better labor relations, more economical buying arrangements, a cheaper system of distribution, lower labor costs, lower taxes, younger but more experienced management, lower freight costs, a more experienced labor pool, a more sound financial structure, a more stable history, better credit, more diversified production, greater earnings, and a more conservative

clusions of the Tax Court respecting value. Phipps v. Commissioner, 127 F.2d 214 (10th Cir. 1942), cert. denied, 317 U.S. 645 (1942). See also Note, 94 U. of PA. L. REV. 365 (1946).

77. Compare the comments in Estate of Brittingham, P-H 1942 TC Mear. Dec. II 42,072 (1942).

78. INT. REv. CoDE $\$ 811(\mathrm{k})$, quoted supra note 5 .

79. For an excellent analysis of recent cases under the statute see Powell, Valu. ation cases: Practical Utility of Listed Comparatives under Recent Decisions, 6 Proc. OF INST. ON FED. TAX'N. 163 (1948). It has been suggested that notwithstanding the statute, the Commissioner has not accorded proper weight to the factor. See Van Dyke, Commissioner Unfair to Fair Market Value, 23 TAXes 788 (1945).

80. Colonial Trust Co. v. Kraemer, 63 F. Supp. 866 (D. Conn. 1945); Horlick v. Kuhl, 62 F. Supp. 168 (E.D. Wis. 1945) and cases cited.

81. See Oxford Paper Co. v. United States, 52 F.2d 1008 (Ct. Cl. 1931), as amended, 56 F.2d 895 (Ct. Cl. 1932) ; Blackard v. Jones, 62 F. Supp. 234 (W.D. Okla. 1944); Brown v. United States, 16 Arr. FED. TAX REp. 1084 (1935); Drayton Cochran, P-H 1948 TC MEMr. Dec. \48,094 (1948); Wm. S. Cherry, P-H 1946 TC MEs. DEC. I 46,140 (1946); Lizzie F. Olney, P-H 1946 TC MEM. DEC. TI 46,138 (1946).

82. Rheinstrom v. Willcut, 26 F. Supp. 306 (D. Minn. 1938); Geo. D. Harter Bank, 38 B.T.A. 387 (1938); James Couzens, 11 B.T.A. 1040 (1928); Jacob Fish, 1 B.T.A. 882 (1925). 
dividend policy. Similar factors dealing with the "value" of each company could be multiplied. In theory every one of these and other relevant factors is compared among several-in one case as many as nine ${ }^{83}$-companies to insure that the stock value of the comparatives is in fact comparable. With respect to each of these factors, several questions must be asked and answered as to each comparative. For example: does the comparative company in fact have sounder labor relations? If so, to what extent is that factor reflected in the value of its stock? To what extent is the factor of less sound labor relations reflected in the stock to be valued? How much more unsound, in terms of dollar equivalents reflected in stock values, are the labor relations of the latter as compared to the former, company? Theoretically, each of these factors is weighed separately, and then the cumulative effect of all the factors is weighed. Of course, this type of inquiry cannot go on if the business of either the government or the taxpayer is to be transacted. In practice, the Commissioner calls "experts" who support his valuation, and the taxpayer calls "experts" who support his valuation. The Tax Court makes some reference to the comparatives in its findings and opinion, and expresses a decision based on "all relevant factors." Actually, the difficulties in determining the extent to which the companies compared are in fact comparable are insurmountable.

Stocks subject to restrictions on sale. Courts have frequently held that enforceable limitations respecting sale must be considered in establishing the "fair market value" of stock. Where the stock to be valued is subject to an option to purchase, at any time, the value of the stock clearly should not exceed the option price. ${ }^{84}$ Accordingly, the Commissioner and the courts in such a case should use the option price instead of asset value. This would be authorized under the hardship clause of the formula.

On the other hand, restrictions on the sale of stock vary. In most cases it is not clear that the effect of the restriction is to limit the value of stock to a specific sum. For example, some cases have involved options which enable the option holder to purchase stock at a stated sum if the stockholder decides to sell ${ }^{85}$ or terminates his employment with the company. ${ }^{86}$ In such cases it has been held that the restriction

83. Lizzie F. Olney, P-H 1946 TC MEM. DEc. II 46,138 (1946).

84. The courts have adopted this approach under the present valuation system. Helvering v. Salvage, 297 U.S. 106 (1936); Commissioner v. Bensel, 100 F.2d 639 (3d Cir. 1938); Lomb v. Sugden, 82 F.2d 166 (2d Cir. 1936); Wilson v. Bowers, 57 F.2d 682 (2d Cir. 1932) ; John Mitchell, 37 B.T.A. 1 (1938). Compare Kline v. Commissioner, 130 F.2d 742 (3d Cir. 1942).

85. Worcester County Trust Co. v. Commissioner, 134 F.2d 578 (1st Cir. 1943).

86. Commissioner v. McCann, 146 F.2d 385 (2d Cir. 1944); Krauss v. U.S., 140 F.2d 510 (5th Cir. 1944); Kline v. Commissioner, 130 F.2d 742 (3d Cir. 1942). 
is not controlling, but should be considered as a relevant factor in determining the "value" of the stock. ${ }^{87}$ In some cases involving absolute restrictions on sale for a limited period of time, reliance has been placed on net worth of assets to determine the value of the stock. ${ }^{88}$

The speculative nature of this approach to "value" is manifest. The result may be illustrated by a case involving restrictions of by-laws, where, upon termination of employment, an employee was obligated to sell the stock at book value and the corporation was obligated to buy. The appellate court said that this factor should have been considered by the Tax Court in fixing "value" :

We say nothing as to how the shares shall be appraised; that is the Tax Court's duty, from any interference in which we must rigidly abstain. It may come to the same conclusion after weighing all the relevant factors : the prospective earnings; the likelihood that the donor would not retire; his expectancy of life; his power to change the by-laws; his opportunity to sell, to another employee - with the director's consent-; and any other factor which it finds would contribute to, or detract from, the value. All we decide is that it was, as a matter of law, erroneous to refuse to consider any other factor than the book value at the time of the gift; so far we understand we are obliged to go. ${ }^{89}$

The conjecture involved in such an inquiry makes impossible a rational analysis of the dollar result. Use of a formula based on the asset value of the stock would reach a generally equitable result without such speculation. The result would be sound in practice because directly related to the value of the stock to the holder; it would accord with the theory of the formula, which excludes from consideration factors affecting sale price.

\section{"Fatrness" Under Proposed Formula}

Comparison with the current valuation process. The foregoing discussion of blockage, business prospects and restrictive agreements respecting the sale of close held stock is not intended to imply that the existence of such factors bears no relevance to the "value" of the stock. Obviously, if the stock to be valued represents a block readily marketable, and subject to no restrictions respecting sale, the value of the stock to the owner and the market price of the stock may be greater

87. See notes 85 and 86 supra. See also Newman v. Commissioner, 40 F.2d 225 , rehearing denied, 41 F.2d 743 (10th Cir. 1930); Frederick A. Koch, 28 B.T.A. 363 (1933).

88. E. F. Simms, 28 B.T.A. 988 (1933); Wallis Tractor Co., 3 B.T.A. 981

(1925). But cf. Helvering v. Tex-Penn Oil Co., 300 U.S. 481 (1937).

89. Commissioner v. McCann, 146 F.2d 385, 386 (2d Cir. 1944). 
than a stock subject to contrary factors. Similarly, if any one of countless "other relevant factors" be shown to exist-such as sound financial condition or excellent business prospects-the value of the stock to the owner, and the market price of the stock, may be enhanced. The basic premise which has supported the current system of translating close held stock into dollar equivalents is that it is unfair to preclude the Commissioner and the courts from considering those circumstances in reaching a decision. The basic difficulty with the current system is that it assumes that the existence of these factors is capable of objective proof and more particularly that an intelligent decision can be made as to the extent that each of these factors influences the worth of the stock to the taxpayer or the sum which he could obtain for it on the market. That a decision respecting such factors must, as a matter of theory, be intuitive to the point of speculation admits of no doubt. Litigants placing their respective reams of evidence into the Tax Court hopper may expect to find the finished product consisting of a result expressed in terms of dollars, packaged in a conglomeration of facts. They will look in vain for "law" in the sense of a predictable guide for the future or a rationalization of all of the factors considered in the decision and the weight accorded to each of them.

This result-which would be bad in any case-is particularly unfortunate where the process is directed to discovering the dollar equivalent of property for purposes of Federal taxation. Taxation is not concerned with the philosophical meaning of "value"; if government is to go on, it cannot even be concerned with an absolute balance which will insure that every taxpayer shall pay his exact proportion of the cost of government. There is no such balance in a system under which corporations must pay an income tax but partnerships and cooperatives do not; where only one half of the total gain from capital assets held in excess of six months is included in ordinary income, and all gain from capital assets held less than six months is included in ordinary income. There is no such balance in the valuation process itself. The market price for stocks may be influenced by manic or depressive mass psychoses in Wall Street or Washington, unrelated to what many would agree to be "value," but in most cases the market price nevertheless controls the "value" for tax purposes. A reversionary or remainder interest in an estate is valued on the basis of the mortality tables, notwithstanding that a life estate may in fact be terminated one day or fifty years after the death of the decedent. ${ }^{90}$ The basis for these rules

90. It was held in Ithaca Trust Co. v. United States, 279 U.S. 151 (1929) that the value of a life estate must be determined on the basis of life expectancy at testator's death, notwithstanding that the life tenant died before the time for computing the tax. Note also the frequently quoted opinion of Judge Frank in Commissioner 
is well established: from the standpoint of both the government and the taxpayer, it may be more "fair" to settle these issues promptly by application of a generally fair rule than to engage in unprofitable, expensive and administratively unwise attempts to obtain an exactly proportionate division of the tax burden. As Justice Brandies once suggested, ${ }^{91}$ it is sometimes more important to solve a problem than to solve it right.

These observations apply particularly to the complaint sometimes made informally by practitioners that stock without a market value is currently valued by the Commissioner and the courts at a higher figure than actually comparable stock valued on the basis of market quotations. It has not been demonstrated that this result is general: the nature of the problem precludes a facile conclusion on the point. Practitioners also complain that this result is reached because the Commissioner currently applies the net asset value formula to close held stock. The accuracy of this statement may be equally difficult to demonstrate; but it would not be surprising to find the Commissioner currently relying on the net asset value formula at least to the extent that it provides a relatively tangible guide to the establishment of value. The answer to these criticisms is twofold. There is no lack of logic in a process which reaches the dollar equivalent of stock by taking the market value where one exists, and substituting the aliquot net asset value of the corporation where no market value is obtainable. And if it be assumed-as it

v. Marshall, 125 F.2d 943 (2d Cir, 1942), holding that the actuarial method of valuing remainders for gift tax purposes was "not so arbitrary as to be unreasonable and invalid." The court said further: "It is immaterial that actuarial estimates may not accord with realities. Few estimates of value do, whether used by courts or laymen: For purposes of corporate reorganization, value, generally, is a reasonable capitalization of future earnings as reasonably foreseeable at the date of reorganization; reliance is had upon an educated guess or peering into the future, which, being a human conjecture, may be wrong. No one can foretell what changes in technology will do to the earnings of any business. Any one who wants to eliminate uncertainties from 'value' will have a sad time getting along in this world. All aspects of living are chancy. We cannot, by the use of a symbol, 'value', convert the risky into risklessness, Canute restless change out of existence. Businessmen sometimes pay cash for value which exists only in 'moonshine or dreamland.' . . . Accordingly, we reject the argument that, merely because the 'value' of the contingent remainders, measured actuarially, may be inaccurate, Congress must be deemed to have intended that such remainders should not be subject to a gift tax." Of course, even under such a formula the courts can avoid a clearly unjust result. See United States v. Provident Trust Co., 291 U.S. 272 (1934); Estate of Denbigh, 7 TC 387 (1946) ; 60 HARv. L. Rev. 152 (1946).

We have recently relearned also that where a life estate is given to an individual with the remainder over to charity, no deduction for the remainder is permissible where the trustee is directed to invade the corpus to provide for the individual "in such manner as she may desire." Henslee v. Union Planters National Bank and Trust Co., 69 Sup. Ct. 290 (1949). In that case it was abundantly clear that there was only the most remote possibility that the corpus would ever be impaired, but evidence on this subject was held irrelevant on the authority of Merchants National Bank of Boston v. Commissioner, 320 U.S. 256 (1943).

91. Burnet v. Coronado Oil and Gas Co., 285 U.S. 393, 406 (1932) (dissenting opinion),". - in most matters it is more important that the applicable rule of law be settled than that it be settled right." 
has yet to be generally demonstrated-that the valuations thus made are higher for close held stock than stock with a market value, this does not demonstrate that either method is more "fair." In both cases the dollar "value" is necessarily artificial; there is no magic in either interpretation. There is in each interpretation, however, a maximum of the kind of certainty and predictability by which men may be reasonably guided in computing tax liability.

Further, it would be illusory to attempt to establish that the "fair" answer was reached in any case or in any percentage of cases under current methods of valuing close held stock, on whatever theory they may have been decided. The fact is that there are no "right" answers. A comparison of the values asserted by the Commissioner and the taxpayers in a random selection of cases is printed in the margin. ${ }^{22}$ The

92. Comparison of values claimed by litigants in tax cases:

In re Nathan's Estate, 166 F.2d 422 (9th Cir. 1948)

Worcester County Trust Co. v. Commissioner, 134 F.2d 578 (1st Cir. 1943)

Hazeltine Corp. v. Commissioner, 89 F.2d 513 (3rd Cir. 1937)

Brooks v. Willcuts, 78 F.2d 270 (8th Cir. 1935)

Robettson v. Routzahn, 75 F.2d 537 (6th Cir. 1935)

Newell v. Commissioner, 66 F.2d 102 (7th Cir. 1933)

Commissioner v. Johnson, 51 F.2d 1075 (6th Cir. 1931)

\begin{tabular}{|c|c|}
\hline $\begin{array}{l}\text { VALUATION } \\
\text { ASSERTED BY } \\
\text { TAXPAYER }\end{array}$ & $\begin{array}{l}\text { VALUATTON } \\
\text { ASSERTED BY } \\
\text { COMMISSIONER }\end{array}$ \\
\hline $\begin{array}{r}297.66 \\
1,750.00\end{array}$ & $\begin{array}{r}\$ 1,000.00 \\
3,900.00\end{array}$ \\
\hline 15.46 & 35.00 \\
\hline 18.63 & 10.00 \\
\hline 140.00 & 175.00 \\
\hline 785.00 & 431.85 \\
\hline $\begin{array}{r}75.00 \\
154.10\end{array}$ & $\begin{array}{l}100.00 \\
250.00\end{array}$ \\
\hline 117.00 & 285.00 \\
\hline 22.50 & 15.25 \\
\hline 75.32 & 93.70 \\
\hline 48.12 & 72.70 \\
\hline .50 & 1.00 \\
\hline 58.50 & 90.00 \\
\hline 129.00 & 316.52 \\
\hline 750.00 & $2,056.00$ \\
\hline $\begin{array}{l}79.68 \\
56.50\end{array}$ & $\begin{array}{l}150.00 \\
340.00\end{array}$ \\
\hline $\begin{array}{l}20.00 \\
60.00\end{array}$ & $\begin{array}{l}100.00 \\
100.00\end{array}$ \\
\hline 20.00 & 100.00 \\
\hline $\begin{array}{r}758.00 \\
6,046.00\end{array}$ & $\begin{array}{r}1,760.60 \\
15,043.66\end{array}$ \\
\hline $\begin{array}{r}50.00 \\
5.00\end{array}$ & $\begin{array}{l}95.00 \\
15.00\end{array}$ \\
\hline 30.00 & 44.00 \\
\hline 150.00 & 857.00 \\
\hline 160.00 & 400.00 \\
\hline 58.72 & 149.00 \\
\hline $2,055.79$ & $13,000.00$ \\
\hline
\end{tabular}

Phillips v. United States, 12 F.2d 598 (W.D. Pa. 1926), aff'd, 24 F.2d 195 (3rd Cir. 1928)

Horlick v. Kuhl, 62 F. Supp. 168 (E.D. Wis. 1945)

Baker v. Hoey, 33 F. Supp. 799 (S.D.N.Y. 1933)

Wood v. United States, 29 F. Supp. 853 (Ct. Cl. 1939)

Mary· E. Cook, 9 T.C. 563 (1947)

Ambrose Fry, 9 T.C. 503 (1947)

Amy H. DuPuy, 9 T.C. 276 (1947)

Lelia E. Coulter, 7 T.C. 1280 (1946)

Augustus E. Staley, 41 B.T.A. 752 (1940)

Mathilde B. Hooper, 41 B.T.A. 114 (1940)

Mary A. Laird, 38 B.T.A. 926 (1938)

Geo. D. Harter Bank, 38 B.T.A. 387 (1938)

Safe Deposit and Trust Co., 35 B.T.A. 259 (1937)

Kanawha Banking \& Trust Co., 29 B.T.A. 376 (1933)

Jos. H. Holmes, 22 B.T.A. 757 (1931)

Wm. Schoenheit, 14 B.T.A. 33 (1928)

James Couzens, 11 B.T.A. 1040 (1928) 
figures represent the extremes claimed at different times during negotiation and trial and may not be representative of the divergence of views in cases which are not litigated. But assuming that neither party is claiming a "value" beyond reasonable expectation of proof, the sum claimed demonstrates that there is ample room for reasonable divergence of opinion as to the "value" of any block of close held stock. Except where some specific and recurring principle is involved, such as blockage, it is impossible to demonstrate any real or fancied misunderstanding of facts or economics in a decision. Accordingly, it is impossible to establish that the decisions are either right or wrong. Still less is it possible to demonstrate that the decisions have been more "fair" than those which may be expected under the proposed formula. It should, however, be noted that in several cases decided by the Tax Court during recent years, a figure has been adopted which roughly represents a mathematical compromise between the respective "values"

Justin Potter, P-H 1948 TC MEN. DEc. $\llbracket 48,062$ (1948)

Charles E. Kimball, P-H 1946 TC MeN. Dec. $\pi 46,268$ (1946)

Lizzie F. Olney, P-H 1946 TC MeM. Dec $\llbracket 46,138$ (1946)

James Hogan, P-H 1944 TC MEM. DEC $\llbracket 44,109$ (1944)

Sarah H. Bradley, P-H 1943 TC MEar. DEc. If 43,382 (1943)

L. J. Burda, P-H 1943 TC MENr. DeC. $\pi 43,350$ (1943)

Herbert L. Johnston, P-H 1943 TC MEAr. DEC. II 43,296 (1943)

John B. Bryan, P-H 1943 TC Mear. Dec. If 43,208 (1943)

Hettie M. Stroh, P-H 1943 TC MEM. DEc. II 43,031 (1943)

Herman B. Good, P-H 1942 TC Mear. Dec. I 42,529 (1942)

Rathbun Fuller, P-H 1942 TC MEM. DEC. II 42,443 (1942)

Harold H. Brittingham, P-H 1942 TC MEM. DEC. II 42,072 (1942)

Reba S. Buchanan, P-H 1941 BTA MeM. DEc. If 41,091 (1941)

John B. Waterman, P-H 1941 BTA MeM. Dec. II 41,551 (1941)

Frederick J. Kieser, P-H 1940 BTA MEM. DEc. If 40,240 (1940)

Margaret Russell Vail, P-H 1940 BTA MEM. Dec. $\{40,431$ (1940)

Victor A. Machris, P-H 1938 BTA MEM. DEC. (f 38,076 (1938)
VALUATION

ASSERTED BY

TAXPAYER

25.00

3.00

1.39

15.00

100.00

676.00

$1,125.00$

121.00

3.00

31.00

50.00

381.56

90.00

35.00

50.00

423.12

160.00

42.50

50.00

53.35

221.25
Valuation

ASSERTED BY

Commisstoner

90.00

75.00

4.00

22.50

350.00

$1,100.00$

$2,100.00$

430.00

10.00

50.00

75.00

620.40

150.00

135.00

75.00

625.00

478.00

100.00

120.00

152.42 
claimed by the Commissioner and the taxpayer. ${ }^{93}$ The results were unquestionably reached after weighing of the evidence. And, as the Tax Court has reminded us, a decision has to be made somehow. But, particularly in the absence of a rationalization for the result, the cases can scarcely be said to demonstrate that decisions under the present process are more "fair" than decisions would be under the proposed formula.

Moreover, the "value" of stock today has been thought to depend on the prospects for tomorrow. Management which is poor today may be competent tomorrow; competition may increase or lessen; markets may broaden or contract; the ratio of current assets to current liabilities may change; the business outlook may grow more dim or bright. Thus "value" in fact is determined by the future, and every decision is based-at least in theory-on what the future holds for the corporation which issued the stock to be valued. Notwithstanding the grandiose claims of the broker's tip sheet, prescience of this sort is not given to man; but under the present valuation process it is mandatory that the litigants aspire to it and that the Tax Court attain it as best it can. This type of prediction should be the last-not the first-resort in the search for a fair and efficient system of tax administration.

\section{ConCLuSION}

Any formula proposed must rest primarily on what is "fair." The exact content of any formula suggested is accordingly debatable. Various modifications in the formula proposed may well be thought desirable by different persons. Changes in the formula may be necessary to make it more palatable to Congress or those who influence legislation on the subject. Certainly no formula should be so burdened with multiple factors that a determination of "value" would remain as subjective as it is at present. Subject to this limitation the exact nature and scope of the formula can safely be left to legislative determination.

It is submitted, however, that the formula proposed represents a

93. Comparison of values asked by litigants and given by Tax Court:

Mary E. Cook, 9 T.C. 563 (1947)

Ambrose Fry, 9 T.C. 503 (1947)

Amy H. DuPuy, 9 T.C. 276 (1947)

Lelia E. Coulter, 7 T.C. 1280 (1946)

Lizzie F. Olney, P-H 1946 TC MEM. DEc. \ 46,138 (1946)

Hettie M. Stroh, P-H 1943 TC MEM.

Dec. If 43,031 (1943)

\begin{tabular}{|c|c|c|c|}
\hline $\begin{array}{l}\text { VAI } \\
\text { AsS } \\
\text { TAS }\end{array}$ & $\begin{array}{l}\text { UATION } \\
\text { URTED BY } \\
\text { UPAYER }\end{array}$ & $\begin{array}{l}\text { VALUATION } \\
\text { ASSERTED BY } \\
\text { COMMISSIONER }\end{array}$ & $\begin{array}{l}\text { VALUATION } \\
\text { FOUND BY } \\
\text { TAX COURT }\end{array}$ \\
\hline$\$$ & 58.50 & $\$ 90.00$ & $\$ 75.00$ \\
\hline & 129.00 & 316.52 & 245.00 \\
\hline & 750.00 & $2,056.00$ & $1,300.00$ \\
\hline & 79.68 & 150.00 & 90.00 \\
\hline & 676.00 & $1,100.00$ & 855.00 \\
\hline & 381.56 & 620.40 & 465.00 \\
\hline
\end{tabular}


reasonable approach to the problem of valuation. It is sufficiently flexible so that it will not become "a doctrine so enamoured of accuracy" that the Commissioner and the Tax Court must abdicate the function of decision. At the same time, it has the undoubted virtue that it will canalize the investigation of "value." Instead of consulting "all relevant factors" the Tax Court will consider the single factor most relevant to a fair and efficient system of tax administration. The taxpayer and the Commissioner, knowing the issues to be determined, may more readily present evidence directed to specific issues, determinable by specific provisions of the statute and regulations. While the ultimate determination will remain subjective in the sense that a subjective process is involved in measuring any set of facts by a rule of law, a rational statement of the exact bases for the decision may be expected and required. Litigants will know more of why they won or lost their cases; the Tax Court itself may begin to build a more orderly and concrete legal structure for the guidance of the public. The presumption supporting the findings of the Commissioner may be weighed against the statutory directions for determining "value," and the determination of the Tax Court may be measurable by a yardstick of law rather than weighing the speculative decision of the Tax Court against the intuitive decision of the appellate court. The adoption of a measurable policy will insure more consistent valuations throughout the various offices of the Bureau; settlements without litigation will be facilitated where the issues are known. The delays, expense and uncertainties incident to the present valuation process will be reduced.

The interests of the taxpayers and the government alike require a change. 